\title{
ANALISIS SEKTOR UNGGULAN DAN PENGEMBANGAN WILAYAH DI KABUPATEN BOLAANG MONGONDOW TIMUR
}

\author{
Elein Mamahit \\ Paulus A. Pangemanan \\ Charles R. Ngangi
}

\begin{abstract}
This study aims to (1) identify the leading sectors in the economic structure of East Bolaang Mongondow Regency as information and consideration in (2) formulating regional development strategies. This study uses time series data from Gross Regional Domestic Product (PDRB) of East Bolaang Mongondow Regency and North Sulawesi Province in 2010 - 2016. The analysis tool used in this research is Klassen Tipology, Location Quotient $(L Q)$, and Shift Share analysis to determine the leading sectors and SWOT analysis. The result of per sector analysis based on these three analytical tools shows that which is the leading sector in East Bolaang Mongondow Regency with criteria of advanced and fast growing sector, basic and competitive sector, there are 2 sectors: (a) agriculture, forestry and fishery sector, (b) mining and quarrying sectors. To formulate regional development strategy used SWOT analysis tool. Based on the SWOT analysis, the strategy of regional development at East Bolaang Mongondow Regency with the superior sector is in quadrant III so that the appropriate strategy is turn around strategy. The Weakness Opportunity Strategy in Quadrant III, means minimizing weaknesses by taking advantage of opportunities.
\end{abstract}

Keywords: superior sector, regional development, klassen tipology, location quotient, shift share, SWOT

\begin{abstract}
ABSTRAK
Penelitian ini bertujuan untuk (1) mengidentifikasi sektor unggulan dalam struktur perekonomian Kabupaten Bolaang Mongondow Timur sebagai bahan informasi dan pertimbangan dalam (2) merumuskan strategi pengembangan wilayah. Penelitian ini menggunakan data sekunder berupa runtun waktu (time series) dari Produk Domestik Regional Bruto (PDRB) Kabupaten Bolaang Mongondow Timur dan Provinsi Sulawesi Utara tahun 2010 - 2016. Alat analisis yang digunakan dalam penelitian ini, yaitu analisis Tipologi Klassen, Location Quotient (LQ), dan analisis Shift Share untuk menentukan sektor unggulan serta analisis SWOT. Hasil analisis per sektor berdasarkan ketiga alat analisis ini menunjukkan bahwa yang (1) merupakan sektor unggulan di Kabupaten Bolaang Mongondow Timur dengan kriteria sektor maju dan tumbuh pesat, sektor basis, dan kompetitif ada 2 sektor yaitu (a) sektor pertanian, kehutanan dan perikanan, (b) sektor pertambangan dan penggalian. (2) Untuk merumuskan strategi pengembangan wilayah digunakan alat analisis SWOT. Berdasarkan analisis SWOT posisi pengembangan wilayah Kabupaten Bolaang Mongondow Timur dengan berbasis sektor unggulan berada pada kuadran III sehingga strategi yang sesuai adalah strategi perubahan haluan atau strategi berbalik (turn around). Strategi Weakness Opportunity pada kuadran III, berarti meminimalkan kelemahan dengan memanfaatkan peluang.
\end{abstract}

Kata kunci: Sektor Unggulan, Pengembangan Wilayah, Tipologi Klassen, Location Quotient, Shift Share, SWOT 


\section{PENDAHULUAN}

\section{Latar Belakang}

Pengembangan wilayah merupakan upaya untuk memacu perkembangan sosial ekonomi, mengurangi kesenjangan dan menjaga kelestarian lingkungan hidup pada suatu wilayah. Potensi wilayah berupa pemberian alam maupun hasil karya manusia di masa lalu adalah aset yang harus dimanfaatan untuk kemakmuran rakyat dalam jangka panjang dan bersifat langgeng.

Menurut Anwar dan Rustiadi (2000), akibat keterbatasan sumberdaya yang tersedia, perlu ada skala prioritas pembangunan. Dari sudut dimensi sektor pembangunan, suatu skala prioritas didasarkan atas suatu pemahaman bahwa:

1. Setiap sektor memiliki sumbangan langsung dan tidak langsung yang berbeda terhadap pencapaian sasaran-sasaran pembangunan (penyerapan tenaga kerja, pendapatan regional, dan lain-lain);

2. Setiap sektor memiliki keterkaitan dengan sektor-sektor lainnya dengan karakteristik yang berbeda-beda;

3. Aktivitas sektoral menyebar secara tidak merata dan spesifik; beberapa sektor cenderung memiliki aktivitas yang terpusat dan terkait dengan sebaran sumberdaya alam, sumberdaya buatan (infrastruktur), dan sumberdaya sosial yang ada.

Oleh karena itu menurut Anwar dan Rustiadi (2000), setiap daerah mempunyai sektor-sektor unggulan yang memberikan dampak signifikan terhadap pengembangan ekonomi wilayah. Pengembangan terhadap sektor-sektor unggulan ini akan menyebabkan pengembangan sektorsektor lainnya yang berkaitan dalam suatu wilayah tertentu. Identifikasi sektor unggulan menjadi bagian penting yang tidak dapat dipisahkan dalam mencapai tujuan pembangunan secara efektif dan efisien. Adanya kebijakan pengembangan wilayah berdasarkan pada prioritas dapat menghasilkan suatu kebijakan yang lebih terarah sehingga mengurangi risiko kesiasiaan pemanfaatan sumberdaya.

Kabupaten Bolaang Mongondow Timur merupakan daerah otonom baru hasil pemekaran dari kabupaten Bolaang Mongondow yang dibentuk berdasarkan Undang-undang Nomor 29 Tahun 2008 tentang pembentukan Kabupaten Bolaang Mongondow Timur di Provinsi Sulawesi Utara dengan ibukota Tutuyan, mempunyai luas wilayah rata-rata $910.176 \mathrm{Km}^{2}$ atau $91.017,6 \mathrm{Ha}$ dan jumlah penduduk di tahun 2016 sebesar 69.716 jiwa.
Dengan adanya otonomi daerah, pemerintah daerah memiliki kewenangan lebih untuk bisa semakin menggali potensi daerah yang dimiliki. Menjadi tantangan bagi Kabupaten Bolaang Mongondow Timur sebagai daerah otonom baru, yaitu bagaimana mewujudkan pengembangan wilayah yang tepat sehingga dapat mencapai kemandirian wilayah seperti filosofi awal dari otonomi daerah. Untuk menuju kemandirian harus dapat menggali potensi yang dimiliki dan mengembangkan potensi-potensi tersebut menjadi berbagai kegiatan ekonomi yang menghasilkan nilai tambah dan berdaya saing tinggi. Dengan demikian pengembangan wilayah perlu memperhatikan sektor-sektor unggulan yang mampu memberikan efek ganda (multiplier effect) yang besar terhadap sektor-sektor lainnya dan perekonomian secara keseluruhan.

\section{Pembangunan dan pengembangan wilayah}

Perencanaan wilayah pada dasarnya merupakan upaya intervensi terhadap kekuatankekuatan pasar yang dalam konteks pengembangan wilayah memiliki tujuan pokok, yakni meminimalkan konflik kepentingan antar sektor, meningkatkan kemajuan sektoral, dan membawa kemajuan bagi masyarakat secara keseluruhan. Menurut Suwardji dan Tejowulan (2008), pengembangan wilayah adalah segala upaya perbaikan suatu atau beberapa jenis wilayah agar semua komponen yang ada di wilayah tersebut dapat berfungsi dan menjalankan kehidupan secara normal.

Pembangunan wilayah ditopang oleh empat pilar yaitu sumberdaya alam/fisik lingkungan, sumberdaya buatan/ekonomi, sumber daya manusia dan sumber daya sosial kelembagaan. Seperti yang diungkapkan oleh Misra (1982), pengembangan wilayah merupakan upaya untuk mendorong terjadinya perkembangan wilayah secara harmonis melalui pendekatan yang bersifat komprehensif mencakup aspek fisik, ekonomi, sosial dan budaya. Menurut Adisasmita (2008),

\section{Sektor Unggulan dan Kriteria Sektor Unggulan}

Sektor unggulan adalah sektor yang keberadaannya pada saat ini telah berperan besar kepada perkembangan perekonomian suatu wilayah, karena mempunyai keunggulankeunggulan. Selanjutnya faktor ini berkembang lebih lanjut melalui kegiatan investasi dan menjadi tumpuhan kegiatan ekonomi. Hal ini didasarkan atas seberapa besar peranan sektor tersebut dalam perekonomian daerah (Sambodo 
dalam Usya, 2006). Oleh karena itu sektor unggulan menjadi bagian penting dalam pembangunan ekonomi wilayah.

Pengertian sektor unggulan biasanya berkaitan dengan suatu perbandingan, baik itu perbandingan berskala regional, nasional maupun internasional. Pada lingkup internasional, suatu sektor dikatakan unggulan jika sektor tersebut mampu bersaing dengan sektor yang sama dengan negara lain. Sedangkan pada lingkup nasional, suatu sektor dapat dikategorikan sebagai sektor unggulan apabila sektor di wilayah tertentu mampu bersaing dengan sektor yang sama yang dihasilkan oleh wilayah lain, baik di pasar nasional ataupun domestik (Tambunan, 2001). Perbedaan tingkat pembangunan yang di dasarkan atas potensi suatu daerah, berdampak terjadinya perbedaan sektoral dalam pembentukan Produk Domestik Regional Bruto (PDRB). Secara hipotesis dapat dirumuskan bahwa semakin besar peranan potensi sektor ekonomi yang memiliki nilai tambah terhadap pembentukan atau pertumbuhan PDRB di suatu daerah, maka semakin tinggi laju pertumbuhan PDRB daerah tersebut.

\section{Pengembangan sektor unggulan sebagai strategi pembangunan daerah}

Menurut Arsyad (1999:108) permasalahan pokok dalam pembangunan daerah adalah terletak pada penekanan kebijakan-kebijakan pembangunan yang di dasarkan pada kekhasan daerah yang bersangkutan (endogenous development) dengan menggunakan potensi sumber daya manusia. Orientasi ini mengarahkan pada pengambilan inisiatif-inisiatif yang berasal dari daerah tersebut dalam proses pembangunan untuk menciptakan kesempatan kerja baru dan merangsang peningkatan ekonomi. Menurut pemikiran ekonomi klasik bahwa pembangunan ekonomi di daerah yang kaya sumber daya alam akan lebih maju dan masyarakatnya lebih makmur dibandingkan di daerah yang miskin sumber daya alam. Hingga tingkat tertentu, anggapan ini masih bisa dibenarkan, dalam artian sumber daya alam harus dilihat sebagai modal awal untuk pembangunan yang selanjutnya harus dikembangkan terus. Dan untuk ini diperlukan faktor-faktor lain, diantaranya yang sangat penting adalah teknologi dan sumber daya manusia (Tambunan, 2001:198).

\section{Pendapatan regional}

Produk Domestik Regional Bruto (PDRB) merupakan salah satu indikator penting untuk mengetahui kondisi ekonomi di suatu daerah dalam suatu periode tertentu, baik atas dasar harga berlaku maupun atas dasar harga konstan. PDRB pada dasarnya merupakan jumlah nilai tambah yang dihasilkan oleh seluruh unit usaha dalam suatu daerah tertentu, atau merupakan jumlah nilai barang dan jasa akhir yang dihasilkan oleh seluruh unit ekonomi pada suatu daerah. PDRB atas dasar harga berlaku menggambarkan nilai tambah barang dan jasa yang dihitung menggunakan harga pada tahun berjalan, sedang PDRB atas dasar harga konstan menunjukkan nilai tambah barang dan jasa tersebut yang dihitung menggunakan harga yang berlaku pada satu tahun tertentu sebagai tahun dasar. PDRB menurut harga berlaku digunakan untuk mengetahui kemampuan sumber daya ekonomi, pergeseran, dan struktur ekonomi suatu daerah

\section{Rumusan Masalah}

Sehubungan dengan hal-hal yang telah diungkapkan sebelumnya, dapat dirumuskan beberapa pokok permasalahan yang akan dikaji dalam penelitian ini, yaitu:

1. Apa yang menjadi sektor unggulan dalam struktur perekonomian Kabupaten Bolaang Mongondow Timur?

2. Bagaimana strategi pengembangan wilayah di Kabupaten Bolaang Mongondow Timur dengan memperhatikan hasil analisis sektor unggulan?

\section{Tujuan Penelitian}

Tujuan dilaksanakan penelitian ini adalah untuk :

1. Mengidentifikasi sektor-sektor unggulan dalam struktur perekonomian Kabupaten Bolaang Mongondow Timur.

2. Merumuskan strategi pengembangan wilayah di kabupaten Bolaang Mongondow Timur dengan memperhatikan hasil analisis sektor unggulan.

\section{Manfaat Penelitian}

Hasil dari penelitian ini diharapkan dapat menjadi masukan bagi pengembangan wilayah Kabupaten Bolaang Mongondow Timur untuk semua pemangku kebijakan pada umumnya dan terutama pemerintah daerah Kabupaten Bolaang Mongondow Timur pada khususnya. Selain itu, penelitian ini bisa digunakan sebagai dasar penelitian lanjutan yang berkaitan dengan wilayah Kabupaten Bolaang Mongondow Timur. 


\section{METODOLOGI PENELITIAN}

\section{Metode Analisis}

Metode analisis yang digunakan dalam penelitian ini menggunakan dua analisis, yaitu analisis kuantitatif dan kualitatif. Untuk menjawab permasalahan yang telah ditetapkan, maka digunakan beberapa metode analisis data. Analisis Tipologi Klassen digunakan untuk memperoleh klasifikasi pertumbuhan sektor perekonomian wilayah Kabupaten Bolaang Mongondow Timur dan untuk menentukan apakah sektor basis atau non basis digunakan analisis Location Quotient (LQ). Selanjutnya untuk mengetahui perubahan dan pergeseran sektor perekonomian digunakan analisis Shift Share. Hasil akhir dari analisis ini adalah menentukan strategi dan kebijakan pengembangan wilayah Kabupaten Bolaang Mongondow Timur berbasis sektor unggulan menggunakan analisis SWOT.

Analisis Kuantitatif

a. Tipologi Klassen. Pemerintah daerah perlu membuat prioritas kebijakan agar pembangunan daerah dapat berjalan sesuai rencana. Terkait dengan kebijakan anggaran, penentuan prioritas kebijakan tentang pengeluaran daerah merupakan hal yang penting. Penentuan prioritas kebijakan tersebut dapat diwujudkan salah satunya dengan menentukan sektor-sektor prioritas atau unggulan. Tipologi Klassen merupakan alat analisis ekonomi regional yang dapat digunakan untuk mengetahui klasifikasi sektor perekonomian wilayah Kabupaten Bolaang Mongondow Timur. Analisis Tipologi Klassen digunakan dengan tujuan mengidentifikasi posisi sektor perekonomian Kabupaten Bolaang Mongondow Timur dengan memperhatikan sektor perekonomian Provinsi Sulawesi Utara sebagai daerah referensi. Melalui analisis ini diperoleh empat karateristik pola dan struktur pertumbuhan ekonomi yang berbeda, yaitu: sektor cepat-maju dan cepattumbuh (high growth and high income), sektor maju tapi tertekan (high income but low growth), sektor berkembang cepat (high growth but income), dan sektor relatif tertinggal (low growth and low income). Klasifikasi tipologi Klassen digambarkan pada Tabel 1.
Tabel 1 Matriks Tipologi Klassen Pendekatan Sektoral

\begin{tabular}{|c|c|c|c|}
\hline \multirow{2}{*}{\multicolumn{2}{|c|}{ Kriteria }} & \multicolumn{2}{|c|}{ Kontribusi terhadap PDRB } \\
\hline & & $\mathrm{y}_{1} \leq \mathrm{y}$ & $\mathrm{y}_{1} \geq \mathrm{y}$ \\
\hline \multirow{2}{*}{$\begin{array}{c}\text { Laju } \\
\text { Pertumbuhan }\end{array}$} & $\begin{array}{l}\mathrm{r}_{1} \\
\geq \\
\mathrm{r}\end{array}$ & $\begin{array}{c}\text { Kuadran } 3 \\
\text { Sektor } \\
\text { Potensial dan } \\
\text { Masih Dapat } \\
\text { Berkembang } \\
\mathrm{y}_{1} \leq \mathrm{y} \quad \mathrm{r}_{1} \geq \mathrm{r}\end{array}$ & $\begin{array}{l}\text { Kuadran } 1 \\
\text { Sektor } \\
\text { Maju dan } \\
\text { Tumbuh } \\
\text { Cepat } \\
\mathrm{y}_{1} \geq \mathrm{y} \quad \mathrm{r}_{1} \\
\geq \mathrm{r}\end{array}$ \\
\hline & $\begin{array}{l}\mathrm{r}_{1} \\
\leq \\
\mathrm{r}\end{array}$ & $\begin{array}{c}\text { Kuadran } 4 \\
\text { Sektor Relatif } \\
\text { Tertinggal dan } \\
\text { Tumbuh } \\
\text { Lambat } \\
\mathrm{y}_{1} \leq \mathrm{y} \quad \mathrm{r}_{1} \leq \mathrm{r}\end{array}$ & $\begin{array}{l}\text { Kuadran } 2 \\
\text { Sektor } \\
\text { Maju tapi } \\
\text { Tertekan } \\
\mathrm{y}_{1} \geq \mathrm{y} \quad \mathrm{r}_{1} \\
\leq \mathrm{r}\end{array}$ \\
\hline
\end{tabular}

Sumber: Sjafrisal, 2008:180

Sektor yang maju dan tumbuh dengan pesat (Kuadran 1). Kuadran ini merupakan kuadran sektor dengan laju pertumbuhan PDRB $\left(\mathrm{r}_{1}\right)$ yang lebih besar dibandingkan pertumbuhan daerah referensi dalam hal ini Provinsi Sulawesi Utara (r) dan memiliki kontribusi terhadap PDRB $\left(\mathrm{y}_{1}\right)$ yang lebih besar dibandingkan kontribusi sektor tersebut terhadap PDRB Provinsi Sulawesi Utara (y). Klasifikasi ini biasa dilambangkan dengan $r_{1}$ $\geq \mathrm{r}$ dan $\mathrm{y}_{1} \geq \mathrm{y}$. Sektor dalam kuadran 1 dapat pula diartikan sebagai sektor yang potensial karena memiliki kinerja laju pertumbuhan ekonomi dan pangsa yang lebih besar daripada daerah referensi. Sektor maju tapi tertekan (Kuadran II). Sektor yang berada pada kuadran ini memiliki nilai pertumbuhan PDRB $\left(\mathrm{r}_{1}\right)$ yang lebih rendah dibandingkan pertumbuhan PDRB Provinsi Sulawesi Utara (r), tetapi memiliki kontribusi terhadap PDRB daerah $\left(\mathrm{y}_{1}\right)$ yang lebih besar dibandingkan kontribusi nilai sektor tersebut terhadap PDRB Provinsi Sulawesi Utara (y). Klasifikasi ini biasa dilambangkan dengan $\mathrm{y}_{1} \geq \mathrm{y}$ $\mathrm{r}_{1} \leq \mathrm{r}$. Sektor dalam kategori ini juga dapat dikatakan sebagai sektor yang telah jenuh. Sektor potensial atau masih dapat berkembang dengan pesat (Kuadran III). Kuadran ini merupakan kuadran untuk sektor yang memiliki nilai pertumbuhan PDRB $\left(\mathrm{r}_{1}\right)$ yang lebih tinggi dari pertumbuhan PDRB Provinsi Sulawesi Utara (r), tetapi kontribusi sektor tersebut terhadap PDRB $\left(\mathrm{y}_{1}\right)$ lebih kecil dibandingkan nilai kontribusi sektor tersebut terhadap PDRB Provinsi Sulawesi Utara (y). Klasifikasi ini biasa dilambangkan dengan $\mathrm{y}_{1} \leq \mathrm{y} \quad \mathrm{r}_{1} \geq \mathrm{r}$. Sektor dalam 
Kuadran III dapat diartikan sebagai sektor yang sedang booming. Meskipun pangsa pasar daerahnya relatif lebih kecil. Sektor relatif tertingggal (Kuadran IV). Kuadran ini ditempati oleh sektor yang memiliki nilai pertumbuhan PDRB $\left(\mathrm{r}_{1}\right)$ yang lebih rendah dibandingkan pertumbuhan PDRB Provinsi Sulawesi Utara (r) dan sekaligus memiliki kontribusi tersebut terhadap PDRB $\left(\mathrm{y}_{1}\right)$ yang lebih kecil dibandingkan nilai kontribusi sektor tersebut terhadap PDRB Provinsi Sulawesi Utara (y).

b. Location Quotient (LQ). Untuk menentukan sektor basis dan non basis di Kabupaten Bolaang Mongondow Timur digunakan metode analisis Location Quotient (LQ). Metode LQ merupakan salah satu pendekatan yang umum digunakan dalam model ekonomi basis sebagai langkah awal untuk memahami sektor kegiatan dari PDRB Kabupaten Bolaang Mongondow Timur yang menjadi pemacu pertumbuhan. LQ merupakan suatu perbandingan tentang besarnya peranan suatu sektor di Kabupaten Bolaang Mongondow Timur terhadap besarnya peranan sektor tersebut di tingkat Provinsi Sulawesi Utara. Perhitungan dengan menggunakan variabel PDRB dan rumus menghitung LQ adalah:

$$
L Q=\frac{\mathrm{vi} / \mathrm{vt}}{\mathrm{Vi} / \mathrm{Vt}}
$$

Keterangan:

LQ : koefisien Location Quotient

vi : pendapatan sektor i di Kabupaten Bolaang Mongondow Timur

vt : pendapatan total Kabupaten Bolaang Mongondow Timur

Vi : pendapatan sektor i di Provinsi Sulawesi Utara

Vt : pendapatan total Provinsi Sulawesi Utara

Dari perhitungan Location Quotient (LQ) suatu sektor, kriteria umum yang dihasilkan adalah : Jika LQ > 1, berarti bahwa tingkat spesialisasi sektor i di daerah Kabupaten Bolaang Mongondow Timur lebih besar dibandingkan dengan sektor yang sama dalam perekonomian Provinsi Sulawesi Utara. Jika LQ $<1$, berarti bahwa tingkat spesialisasi sektor i di daerah Kabupaten Bolaang Mongondow Timur lebih kecil dibandingkan dengan sektor yang sama dalam perekonomian Provinsi Sulawesi Utara. Jika LQ $=1$, berarti bahwa tingkat spesialisasi sektor i di daerah Kabupaten Bolaang Mongondow Timur adalah sama dengan sektor yang sama dalam perekonomian Provinsi Sulawesi Utara. Apabila nilai LQ>1, maka dapat disimpulkan bahwa sektor tersebut merupakan sektor basis dan potensial untuk dikembangkan sebagai penggerak perekonomian Kabupaten Bolaang Mongondow Timur. Sebaliknya apabila nilai $\mathrm{LQ}<1$, maka sektor tersebut bukan merupakan sektor basis dan kurang potensial untuk dikembangkan sebagai penggerak perekonomian Kabupaten Bolaang Mongondow Timur. Data yang digunakan dalam analisis Location Quotient (LQ) ini adalah PDRB Kabupaten Bolaang Mongondow Timur dan Provinsi Sulawesi Utara tahun 2010-2017 menurut lapangan usaha atas dasar harga konstan tahun 2010.

c. Analisis Shift Share._Analisis Shift-Share dalam penelitian ini dipakai untuk menentukan sektor (kompetitif) unggulan kabupaten Bolaang Mongondow Timur di Provinsi Sulawesi Utara. Data yang digunakan untuk analisis ini adalah data PDRB kabupaten Bolaang Mongondoww Timur dan Provinsi Sulawesi Utara tahun 2010 dan 2016. Hasil Shift-Share Analysis menjelaskan kinerja (performance) suatu sektor di kabupaten Bolaang Mongondow Timur dan membandingkan dengan kinerjanya di dalam Provinsi Sulawesi Utara. Sebagaimana dijelaskan dalam pendahuluan di atas, ShiftShare Analysis digunakan untuk mengetahui perubahan dan pergeseran sektor pada perekonomian Kabupaten Bolaang Mongondow Timur dengan memperhatikan tiga komponen utama yaitu: (1) Provincial Share (PS) atau Komponen Laju Pertumbuhan Total. Komponen ini menyatakan besarnya peranan pertumbuhan ekonomi Provinsi Sulawesi Utara mempengaruhi pertumbuhan ekonomi Kabupaten Bolaang Mongondow Timur. (2) Proportional Shift (P) atau Komponen Pergeseran Proporsional. Komponen ini menyatakan besarnya perubahan relatif suatu sektor ekonomi tingkat Kabupaten Bolaang Mongondow Timur terhadap sektor yang sama di tingkat Provinsi Sulawesi Utara. (3) Differential Shift (D) atau Komponen Pergeseran Diferensial Ukuran ini menjelaskan bagaimana tingkat kompetisi (competitiveness) suatu sektor tertentu di kabupaten Bolaang Mongondow Timur dibandingkan dengan pertumbuhan total sektor tersebut dalam Provinsi Sulawesi Utara. Komponen ini menggambarkan dinamika (keunggulan/ketakunggulan) suatu sektor tertentu di Kabupaten Bolaang Mongondow 
Timur. Persamaan Shift-Share Analysis adalah sebagai berikut :

Dampak nyata pertumbuhan ekonomi wilayah Kabupaten Bolaang Mongondow Timur dengan rumus: $D_{i 1}=N_{i 1}+M_{i 1}+C_{i 1}$

Provincial Share (PS) atau Komponen Laju Pertumbuhan Total, dapat menggunakan rumus: $\mathrm{N}_{\mathrm{i} 1}=\mathrm{E}_{\mathrm{ij}} \mathrm{r}_{2}$

Proportional shift dapat diperoleh dari rumus: $\mathrm{M}_{\mathrm{i} 1}=\mathrm{E}_{\mathrm{i} 1}\left(\mathrm{r}_{\mathrm{i} 2}-\mathrm{r}_{2}\right)$

Differential Shift (D) atau Komponen

Pergeseran Diferensial:

$$
\begin{aligned}
& C_{i 1}=E_{i 1}\left(r_{i 1}-r_{2}\right) \\
& \text { Dimana: } \\
& r_{2}=\left(E_{2, t}-E_{2, t} t_{-1}\right) / E_{2}, t_{-1} \\
& r_{i 2}=\left(E_{i, 2, t}-E_{i, 2, t-1}\right) / E_{i, 2,}, t_{-1} \\
& r_{i 1}=\left(E_{i, 1, t}-E_{1,1}, t_{-1}\right) / E_{i, 1}, t_{-1}
\end{aligned}
$$

Perubahan (pertumbuhan) nilai tambah bruto sektor tertentu (i) dalam PDRB Kabupaten Bolaang Mongondow Timur merupakan penjumlahan Provincial Share, Proportional Shift, dan Differential Shift. Kedua komponen shift, yaitu Proportional Shift (P) dan Differential Shift (D) memisahkan unsur-unsur pertumbuhan regional yang bersifat eksternal dan internal. Proportional Shift $(\mathrm{P})$ merupakan akibat pengaruh unsur-unsur eksternal yang bekerja secara nasional (Provinsi), sedangkan Differential Shift (D) adalah akibat dari pengaruh faktor-faktor yang bekerja di dalam daerah yang bersangkutan. Sektor-sektor di Kabupaten Bolaang Mongondow Timur yang memiliki Differential Shift (D) positif memiliki keunggulan komparatif terhadap sektor yang sama pada Kabupaten/Kota lain dalam Provinsi Sulawesi Utara. Selain itu, sektor-sektor yang memiliki nilai $\mathrm{D}$ positif berarti bahwa sektor tersebut terkonsentrasi di Kabupaten Bolaang Mongondow Timur dan mempunyai pertumbuhan yang lebih cepat dibandingkan dengan daerah lainnya. Apabila nilai D negatif, maka tingkatpertumbuhan sektor tersebut relatif lamban.

\section{HASIL DAN PEMBAHASAN}

\section{Hasil Analisis Sektor Unggulan}

Sektor unggulan merupakan sektor utama yang diharapkan mampu menjadi motor penggerak bagi pertumbuhan ekonomi suatu wilayah, karena mampu memberikan kontribusi besar, kompetitif serta mampu mendorong pertumbuhan sektorsektor yang lain, sehingga sangat berguna dalam mengarahkan pembangunan dan pencapaian sasaran-sasarannya.
Untuk mengetahui sektor apa yang menjadi sektor unggulan daerah kabupaten Bolaang Mongondow Timur maka harus dilakukan suatu perhitungan lebih lanjut. Kriteria suatu sektor unggulan menurut Fachrurrozy (2009) adalah sektor yang maju dan tumbuh dengan pesat, sektor basis, dan memiliki keunggulan komparatif.

1. Klasifikasi Pertumbuhan Sektor

Perekonomian

Analisis Tipologi Klassen digunakan dengan tujuan mengidentifikasi posisi sektor perekonomian Kabupaten Bolaang Mongondow Timur dengan memperhatikan sektor perekonomian Provinsi Sulawesi Utara sebagai daerah referensi. Perhitungan analisis Tipologi Klassen dilakukan dengan melakukan perbandingan: (1) tingkat pertumbuhan sektorsektor ekonomi Kabupaten Bolaang Mongondow Timur dengan tingkat pertumbuhan sektor-sektor ekonomi yang sama tingkat Provinsi Sulawesi Utara. (2) tingkat kontribusi sektor-sektor ekonomi terhadap Produk Domestik Regional Bruto (PDRB) Kabupaten Bolaang Mongondow Timur dengan tingkat kontribusi sektor-sektor ekonomi yang sama di tingkat Provinsi Sulawesi Utara.

Untuk mengetahui posisi laju pertumbuhan sektor ekonomi dan kontribusi sektor ekonomi terhadap PDRB Kabupaten Bolaang Mongondow Timur dan Provinsi Sulawesi Utara selama tahun 2010-2016 dapat dilihat pada Tabel 2 diatas yang memperlihatkan bahwa selama tahun 2010-2016 sektor ekonomi Kabupaten Bolaang Mongondow Timur yang memiliki tingkat pertumbuhan tertinggi adalah sektor konstruksi dengan rata-rata 14,9 persen per tahun, sedangkan yang terendah adalah pertanian, kehutanan dan perikanan dengan rata-rata 4,2 persen per tahun.

Sementara tingkat pertumbuhan sektor ekonomi tertinggi di tingkat Provinsi Sulawesi Utara adalah sektor pengadaan listrik dan gas dengan rata-rata 13,2 persen per tahun, sedangkan yang terendah adalah sektor pertanian dengan rata-rata 3,6 persen per tahun. Sektor ekonomi yang memberikan kontribusi terbesar terhadap PDRB Kabupaten Bolaang Mongondow Timur selama tahun 2010-2016 adalah sektor Pertanian, Kehutanan dan Perikanan dengan rata-rata 36,67 persen per tahun, demikian juga di tingkat provinsi kontribusi terbesar terhadap PDRB Provinsi Sulawesi Utara adalah sektor pertanian dengan rata-rata 21,77 persen per tahun. Hasil perhitungan selanjutnya dimasukkan ke dalam matrik Tipologi Klassen dan dapat dilihat pada 
Tabel 2 Posisi Laju Pertumbuhan dan Kontribusi Rata-Rata

Produk Domestik Regional Bruto Kabupaten Bolaang Mongondow Timur dan Provinsi Sulawesi

LAPANGAN USAHA

Kab. Boltim

Prov. SULUT

Pertumbuhan Kontribusi Pertumbuhan Kontribusi (\%)

$(\%)$

\begin{tabular}{|c|c|c|c|c|c|}
\hline $\mathbf{A}$ & Pertanian, Kehutanan dan Perikanan & 4.2 & 36.67 & 3.6 & 21.77 \\
\hline B & Pertambangan dan Penggalian & 6.8 & 31.09 & 6.7 & 4.88 \\
\hline $\mathbf{C}$ & Industri Pengolahan & 5.6 & 1.58 & 4.5 & 10.79 \\
\hline D & Pengadaaan Listrik dan Gas & 14.7 & 0.04 & 13.2 & 0.10 \\
\hline $\mathbf{E}$ & $\begin{array}{l}\text { Pengadaan Air, Pengelolaan Sampah, } \\
\text { Limbah dan Daur Ulang }\end{array}$ & 4.6 & 0.12 & 4.9 & 0.14 \\
\hline $\mathbf{F}$ & Konstruksi & 14.9 & 6.95 & 7.8 & 12.71 \\
\hline G & $\begin{array}{l}\text { Perdagangan Besar dan Eceran; } \\
\text { Reparasi Mobil dan S. Motor }\end{array}$ & 8.8 & 8.19 & 7.5 & 12.57 \\
\hline $\mathbf{H}$ & Transportasi dan Pergudangan & 6.6 & 1.55 & 7.8 & 8.29 \\
\hline I & $\begin{array}{l}\text { Penyediaan Akomodasi dan Makan } \\
\text { Minum }\end{array}$ & 7.3 & 0.39 & 9.1 & 2.11 \\
\hline $\mathbf{J}$ & Informasi dan Komunikasi & 10.4 & 0.25 & 8.7 & 4.37 \\
\hline $\mathbf{K}$ & Jasa Keuangan dan Asuransi & 6.1 & 0.49 & 8.9 & 3.69 \\
\hline $\mathbf{L}$ & Real Estate & 6.5 & 2.22 & 7.7 & 3.60 \\
\hline $\mathbf{M}, \mathbf{N}$ & Jasa Perusahaan & 6.4 & 0.01 & 8.0 & 0.08 \\
\hline $\mathbf{O}$ & $\begin{array}{l}\text { Administrasi Pemerintahan, } \\
\text { Pertanahan dan Jaminan Sosial Wajib }\end{array}$ & 6.2 & 8.08 & 6.4 & 7.05 \\
\hline $\mathbf{P}$ & Jasa Pendidikan & 6.6 & 0.63 & 5.9 & 2.54 \\
\hline $\mathbf{Q}$ & Jasa Kesehatan dan Kegiatan Sosial & 6.9 & 1.42 & 7.7 & 3.75 \\
\hline $\mathbf{R}$ & Jasa Lainnya & 5.4 & 0.32 & 7.4 & 1.57 \\
\hline
\end{tabular}

Sumber : BPS Kab. Boltim. Tahun 2017, diolah

Tabel 3 yang memperlihatkan bahwa sektorsektor ekonomi Kabupaten Bolaang Mongondow Timur yang masuk dalam Kuadran 1 adalah sektor Pertanian, Kehutanan dan Perikanan dan sektor Pertambangan dan Penggalian. Kedua sektor tersebut memiliki kontribusi dan pertumbuhan yang lebih besar dibandingkan sektor yang sama di tingkat provinsi Sulawesi Utara.

Sektor ekonomi Kabupaten Bolaang Mongondow Timur yang masuk dalam Kuadran 2 hanya sektor Administrasi Pemerintahan, Pertanahan dan Jaminan Sosial. Sektor-sektor tersebut memiliki kemajuan namun mendapatkan tekanan dalam perkembangannya. Kemajuannya terlihat dari sumbangan terhadap PDRB Kabupaten Bolaang Mongondow Timur yang lebih besar dibandingkan dengan sumbangan sektor yang sama terhadap PDRB Provinsi Sulawesi Utara. Tekanan dalam perkembangannya terlihat dari tingkat pertumbuhan PDRB sektor tersebut yang lebih rendah dibandingkan dengan tingkat pertumbuhan PDRB sektor yang sama di tingkat Provinsi Sulawesi Utara.

Sektor-sektor ekonomi Kabupaten Bolaang Mongondow Timur yang masuk dalam Kuadran 3 adalah sektor Industri Pengolahan, sektor Pengadaan Listrik \& Gas, sektor Konstruksi, sektor Informasi dan Komunikasi, sektor Perdagangan Besar dan Eceran, sektor Pendidikan. Sektor-sektor tersebut memiliki potensi dan masih dapat berkembang di masa mendatang. Potensi ini terlihat dari tingkat pertumbuhan PDRB yang lebih tinggi dibandingkan dengan tingkat pertumbuhan PDRB pada sektor yang sama di tingkat Provinsi Sulawesi Utara walau memiliki tingkat kontribusi yang lebih rendah. 
Tabel 3 Klasifikasi Sektor-sektor Perekonomian Kabupaten

Bolaang Mongondow Timur Menurut Tipologi Klassen, 2010-2016

\begin{tabular}{|c|c|c|c|}
\hline \multirow{2}{*}{\multicolumn{2}{|c|}{ Kriteria }} & \multicolumn{2}{|c|}{ Kontribusi terhadap PDRB } \\
\hline & & $\mathrm{y}_{1} \leq \mathrm{y}$ & $\mathrm{y}_{1} \geq \mathrm{y}$ \\
\hline \multirow[t]{3}{*}{$\begin{array}{c}\text { Laju } \\
\text { Pertumbuhan }\end{array}$} & $\mathrm{r}_{1} \geq \mathrm{r}$ & $\begin{array}{c}\text { Kuadran } 3 \\
\text { Sektor Potensial dan Masih Dapat } \\
\text { Berkembang }\end{array}$ & $\begin{array}{c}\text { Kuadran } 1 \\
\text { Sektor Maju dan Tumbuh } \\
\text { Cepat }\end{array}$ \\
\hline & & $\begin{array}{l}\qquad \mathrm{y}_{1} \leq \mathrm{y} \quad \mathrm{r}_{1} \geq \mathrm{r} \\
\text { - Industri Pengolahan } \\
\text { - Pengadaan Listrik \& Gas } \\
\text { - Konstruksi } \\
\text { - Informasi dan Komunikasi } \\
\text { - Perdagangan Besar dan Eceran } \\
\text { - Pendidikan }\end{array}$ & $\begin{array}{l}\quad \mathrm{y}_{1} \geq \mathrm{y} \quad \mathrm{r}_{1} \geq \mathrm{r} \\
\text { - Pertanian, Kehutanan dan } \\
\text { Perikanan } \\
\text { - Pertambangan dan } \\
\text { Penggalian }\end{array}$ \\
\hline & $\mathrm{r}_{1} \leq \mathrm{r}$ & $\begin{array}{l}\text { Kuadran } 4 \\
\text { Sektor Relatif Tertinggal dan Tumbuh } \\
\text { Lambat } \\
\mathrm{y}_{1} \leq \mathrm{y} \quad \mathrm{r}_{1} \leq \mathrm{r} \\
\text { - Pengadaan air, pengelolaan sampah } \\
\text { - Transportasi Pergudangan } \\
\text { - Penyediaan akomodasi, makan } \\
\text { - Jasa Keuangan Asuransi }\end{array}$ & $\begin{array}{c}\text { Kuadran } 2 \\
\text { Sektor Maju tapi Tertekan } \\
\mathrm{y}_{1} \geq \mathrm{y} \quad \mathrm{r}_{1} \leq \mathrm{r} \\
\text { - Administrasi } \\
\text { Pemerintahan, Pertanahan } \\
\text { dan Jaminan Sosial }\end{array}$ \\
\hline
\end{tabular}

Sumber : Hasil Analisis, 2017

2. Analisis Location Quotient (LQ)

Dalam model ekonomi basis sebagai langkah awal untuk memahami sektor kegiatan dari PDRB suatu daerah yang menjadi pemacu pertumbuhan. Analisis LQ digunakan untuk mengidentifikasi sektor basis di Kabupaten Bolaang Mongondow Timur.

3. Analisis Shift-Share

Analisis Shift-Share menggambarkan kinerja sektor-sektor di kabupaten Bolaang Mongondow Timur dibandingkan dengan perekonomian di Provinsi Sulawesi Utara. Bila kabupaten Bolaang Mongondow Timur memperoleh kemajuan sesuai dengan kedudukannya dalam perekonomian propinsi Sulawesi Utara, maka akan dapat ditemukan adanya shift (pergeseran) hasil pembangunan perekonomian daerah. Selain itu, laju pertumbuhan sektor-sektor di kabupaten Bolaang Mongondow Timur akan dibandingkan dengan laju pertumbuhan perekonomian propinsi beserta sektor-sektornya. Kemudian dilakukan analisis terhadap penyimpangan yang terjadi sebagai hasil dari perbandingan tersebut. Bila penyimpangan itu positif, hal itu disebut keunggulan kompetitif dari suatu sektor dalam wilayah tersebut.

Analisis Shift-share untuk perekonomian Kabupaten Bolaang Mongondow Timur dilakukan dengan menggunakan PDRB Kabupaten Bolaang Mongondow Timur menurut Lapangan Usaha tahun 2010 dan 2016 serta PDRB Provinsi Sulawesi Utara menurut Lapangan Usaha tahun 2010 dan 2016. Pada tabel ini nilai PDRB Kabupaten Bolaang Mongondow Timur dihitung perubahannya, yaitu selisih antara nilai PDRB tahun dasar dengan tahun analisis. Berdasarkan data tersebut, nilai PDRB kabupaten Bolaang Mongondow Timur telah mengalami perubahan atau perkembangan. Nilai PDRB tersebut tumbuh sebesar 499,9 miliar rupiah atau sebesar 44,88 persen. . Sedangkan perekonomian provinsi Sulawesi Utara tumbuh sebesar 23.049,73 miliar rupiah atau sebesar 44,57 persen. Tabel 6 dibawah ini menunjukkan distribusi PDRB Kabupaten Bolaang Mongondow Timur dan PDRB Provinsi Sulawesi Utara tahun 2010 dan 2016 (dalam persen) dan Tabel 7 menunjukkan laju pertumbuhan PDRB Kabupaten Bolaang Mongondow Timur dan PDRB Provinsi Sulawesi Utara tahun 2010 dan 2016 (dalam persen). Setelah rumus dasar yang diperlukan dalam analisis Shift-share dihitung, masing-masing komponen pembentuk rumus dapat dihitung. Hasil perhitungan dapat dilihat pada Tabel 8 . Hasil analisis Shift-share menunjukkan bahwa 
Tabel 4 Indeks Location Quotient Sektor-Sektor Ekonomi Kabupaten Bolaang Mongondow Timur dan Provinsi Sulawesi Utara Selama Tahun 2010-2016

\begin{tabular}{clll}
\hline \multicolumn{1}{c}{ LAPANGAN USAHA } & LQ Rata-Rata & & \multicolumn{2}{c}{ Keterangan } \\
\hline A & Pertanian, Kehutanan dan Perikanan & 1.689 & Basis \\
B & Pertambangan dan Penggalian & 6.367 & Basis \\
C & Industri Pengolahan & 0.147 & Non Basis \\
D & Pengadaaan Listrik dan Gas & 0.403 & Non Basis \\
E & Pengadaan Air, Pengelolaan Sampah, Limbah dan Daur Ulang & 0.868 & Non Basis \\
F & Konstruksi & 0.567 & Non Basis \\
G & Perdagangan Besar dan Eceran; Reparasi Mobil dan S. Motor & 0.654 & Non Basis \\
H & Transportasi dan Pergudangan & 0.186 & Non Basis \\
I & Penyediaan Akomodasi dan Makan Minum & 0.183 & Non Basis \\
J & Informasi dan Komunikasi & 0.058 & Non Basis \\
K & Jasa Keuangan dan Asuransi & 0.130 & Non Basis \\
L & Real Estate & 0.611 & Non Basis \\
M,N & Jasa Perusahaan & 0.122 & Non Basis \\
O & Administrasi Pemerintahan, Pertanahan dan Jaminan Sosial Wajib & 1.146 & Basis \\
P & Jasa Pendidikan & 0.248 & Non Basis \\
Q & Jasa Kesehatan dan Kegiatan Sosial & 0.378 & Non Basis \\
R & Jasa Lainnya & 0.203 & Non Basis \\
\hline Sum
\end{tabular}

Sumber : Hasil Analisis, 2017

Tabel 5 PDRB Kabupaten Bolaang Mongondow Timur,

\begin{tabular}{|c|c|c|c|c|c|}
\hline \multirow{2}{*}{\multicolumn{2}{|c|}{ Lapangan Usaha }} & \multicolumn{4}{|c|}{ Kabupaten Bolaang Mongondow Timur } \\
\hline & & \multicolumn{2}{|c|}{ ADHK (Jutaan Rupiah) } & \multicolumn{2}{|c|}{ Perubahan } \\
\hline & & 2010 & 2016 & Absolut & Persen \\
\hline 1 & Pertanian, Kehutanan dan Perikanan & $438.951,6$ & $560.786,1$ & $121.834,4$ & 27.76 \\
\hline 2 & Pertambangan dan Penggalian & $341.714,6$ & $505.839,9$ & $164.125,3$ & 48.03 \\
\hline 3 & Industri Pengolahan & $17.462,14$ & $24.225,3$ & $6.763,2$ & 38.73 \\
\hline 4 & Pengadaaan Listrik dan Gas & 397,78 & 878,2 & 480,4 & 120.78 \\
\hline 5 & $\begin{array}{l}\text { Pengadaan Air, Pengelolaan Sampah, Limbah dan } \\
\text { Daur Ulang }\end{array}$ & $1.446,72$ & $1.895,3$ & 448,6 & 31.01 \\
\hline 6 & Konstruksi & $56.626,0$ & $128.768,9$ & $72.142,8$ & 127.40 \\
\hline 7 & $\begin{array}{l}\text { Perdagangan Besar dan Eceran; Reparasi Mobil dan S. } \\
\text { Motor }\end{array}$ & $85.494,7$ & $141.704,2$ & $56.209,5$ & 65.75 \\
\hline 8 & Transportasi dan Pergudangan & $17.443,6$ & $25.522,9$ & $8.079,3$ & 46.32 \\
\hline 9 & Penyediaan Akomodasi /Makan & $4.257,0$ & $6.509,8$ & $2.252,8$ & 52.92 \\
\hline 10 & Informasi dan Komunikasi & $2.453,6$ & $4.448,3$ & $1.994,6$ & 81.29 \\
\hline 11 & Jasa Keuangan dan Asuransi & $5.602,3$ & $7.977,9$ & $2.375,5$ & 42.40 \\
\hline 12 & Real Estate & $24.923,7$ & $36.448,2$ & $11.524,4$ & 46.24 \\
\hline 13 & Jasa Perusahaan & 108,4 & 157,24 & 48,79 & 44.99 \\
\hline 14 & $\begin{array}{l}\text { Administrasi Pemerintahan, Pertanahan dan Jaminan } \\
\text { Sosial }\end{array}$ & $90.568,5$ & $129.907,7$ & $39.339,2$ & 43.44 \\
\hline 15 & Jasa Pendidikan & $7.005,2$ & $10.263,1$ & $3.257,9$ & 46.51 \\
\hline 16 & Jasa Kesehatan dan Kegiatan Sosial & $15.663,1$ & $23.353,0$ & $7.689,9$ & 49.10 \\
\hline 17 & Jasa Lainnya & $3.748,3$ & $5.126,5$ & $1.378,2$ & 36.77 \\
\hline & Total & $1.113 .867,4$ & $1.613 .812,2$ & $499,944.8$ & 44.88 \\
\hline
\end{tabular}

Sumber : BPS Kab. Boltim. Tahun 2017, diolah 
selama tahun 2010-2016, nilai PDRB Kabupaten Bolaang Mongondow Timur telah mengalami perubahan atau perkembangan. Nilai PDRB tersebut tumbuh sebesar 499,94 miliar rupiah atau sebesar 44,8 sedangkan perekonomian provinsi Sulawesi Utara tumbuh sebesar 23.049,73 miliar rupiah atau sebesar 44,57 persen. Perkembangan tersebut dipengaruhi oleh komponen pertumbuhan ekonomi provinsi Sulawesi Utara (Nij), komponen pergeseran proporsional (Mij), dan keunggulan kompetitif (Cij).

Menurut perhitungan pertumbuhan ekonomi provinsi Sulawesi Utara telah mempengaruhi pertumbuhan ekonomi kabupaten Bolaang Mongondow Timur sebesar 496,39 miliar rupiah atau 99,29 persen. Namun, sebenarnya perkembangan PDRB kabupaten Bolaang Mongondow Timur adalah sebesar499,94 miliar rupiah (Tabel 8). Hal ini dikarenakan masih ada dua komponen lain yang memberikan pengaruh yaitu komponen pergeseran proporsional, dan keunggulan kompetitif. Komponen pergeseran proporsional menyatakan besar perubahan perekonomian wilayah akibat adanya bauran industri memberikan pengaruh yang negatif bagi perkembangan perekonomian kabupaten Bolaang Mongondow Timur cenderung mengarah pada perekonomian yang akan tumbuh relatif lambat. Pada Tabel 8 dapat dilihat sektor-sektor yang memiliki nilai differential positif, yaitu 1) pertanian. Kehutanan dan perikanan (2) sektor pertambangan dan penggalian, (3) sektorindustri pengolahan, (4) sektor pengadaan listrik dan gas, (5) sektor konstruksi, dan (6) sektor perdagangan besar dan eceran; reparasi mobil dan sepeda motor, (7) sektor informasi dan komunikasi, (8) sektor jasa pendidikan. Kondisi tersebut menunjukkan bahwa delapan sektor tersebut mengalami pertumbuhan yang lebih pesat dibanding pertumbuhan ekonomi keseluruhan Provinsi Sulawesi Utara. Di sisi lain, terdapat empat sektor yang memiliki nilai proportional

Tabel 6. Distribusi PDRB Kabupaten Bolaang Mongondow Timur dan PDRB Provinsi Sulawesi Utara tahun 2010 dan 2016 (dalam persen)

\begin{tabular}{llrrrr}
\hline & \multicolumn{1}{c}{ Lapangan Usaha } & \multicolumn{2}{c}{ PDRB } & \multicolumn{2}{c}{ PDRB } \\
\cline { 2 - 5 } & & \multicolumn{1}{c}{ Sulawesi Utara } & \multicolumn{2}{c}{ Bolaang } \\
\hline $\mathbf{1}$ & Pertanian, Kehutanan dan Perikanan & 23.74 & 20.25 & 39.41 & 34.75 \\
$\mathbf{2}$ & Pertambangan dan Penggalian & 4.80 & 4.90 & 30.68 & 31.34 \\
$\mathbf{3}$ & Industri Pengolahan & 11.04 & 9.91 & 1.57 & 1.50 \\
$\mathbf{4}$ & Pengadaaan Listrik dan Gas & 0.09 & 0.13 & 0.04 & 0.05 \\
$\mathbf{5}$ & Pengadaan Air, Pengelolaan Sampah, Limbah dan & 0.15 & 0.13 & 0.13 & 0.12 \\
& Daur Ulang & & & & \\
$\mathbf{6}$ & Konstruksi & 12.17 & 13.19 & 5.08 & 7.98 \\
$\mathbf{7}$ & Perdagangan Besar dan Eceran; Reparasi Mobil dan S. & 12.04 & 12.83 & 7.68 & 8.78 \\
& Motor & & & & \\
$\mathbf{8}$ & Transportasi dan Pergudangan & 8.07 & 8.76 & 1.57 & 1.58 \\
$\mathbf{9}$ & Penyediaan Akomodasi dan Makan Minum & 2.00 & 2.33 & 0.38 & 0.40 \\
$\mathbf{1 0}$ & Informasi dan Komunikasi & & & & \\
$\mathbf{1 1}$ & Jasa Keuangan dan Asuransi & 4.11 & 4.69 & 0.22 & 0.28 \\
$\mathbf{1 2}$ & Real Estate & 3.48 & 3.99 & 0.50 & 0.49 \\
$\mathbf{1 3}$ & Jasa Perusahaan & 3.46 & 3.73 & 2.24 & 2.26 \\
$\mathbf{1 4}$ & Administrasi Pemerintahan, Pertanahan dan Jaminan & 7.08 & 7.08 & 8.13 & 8.05 \\
& Sosial Wajib & & & & \\
$\mathbf{1 5}$ & Jasa Pendidikan & 2.57 & 2.51 & 0.63 & 0.64 \\
$\mathbf{1 6}$ & Jasa Kesehatan dan Kegiatan Sosial & 3.60 & 3.87 & 1.41 & 1.45 \\
$\mathbf{1 7}$ & Jasa Lainnya & 1.52 & 1.61 & 0.34 & 0.32 \\
\hline & & 100.00 & 100.00 & 100.00 & 100.00 \\
\hline
\end{tabular}


shift negatif yaitu (1) sektor pertanian, kehutanan dan perikanan (2) sektor industri pengolahan, (3) sektor pengadaan air pengelolaan sampah, limbah dan daur ulang, (4) sektor jasa pendidikan. Komponen keunggulan kompetitif (Differential Shift) sektor perekonomian Kabupaten Bolaang Mongondow Timur selama tahun 2010-2016 secara keseluruhan diketahui bernilai positif sebesar 65,21 milyar rupiah atau 13,04 persen. Bila dilihat per sektor perekonomian diketahui terdapat delapan sektor yang memiliki differential shift positif yaitu (1) sektor pertanian, kehutanan dan perikanan, (2) sektor pertambangan dan penggalian, (3) sektor industri pengolahan, (4) sektor pengadaan listrik dan gas, (5) sektor konstruksi, (6) sektor perdagangan besar dan eceran; reparasi mobil dan sepeda motor, (7) sektor informasi dan komunikasi, dan (8) sektor jasa pendidikan. Hal ini terjadi karena kedelapan sektor tersebut memiliki kemampuan untuk tumbuh lebih cepat dibandingkan dengan pertumbuhan sektor yang sama di tingkat Provinsi Sulawesi Utara. Di sisi lain, terdapat 9 sektor yang memiliki differential shift negatif yaitu (1) sektor pengadaan air pengelolaan sampah, limbah dan daur ulang, (2) sektor transportasi dan pergudangan, dan (3) sektor penyediaan akomodasi dan makan minum, (4) sektor jasa keuangan dan asuransi, (5) sektor real estate, (6) sektor jasa perusahaan, (7) sektor administrasi

Tabel 7. Laju Pertumbuhan PDRB Kabupaten Bolaang Mongondow Timur dan PDRB Provinsi Sulawesi Utara tahun 2010 dan 2016 (dalam persen)

Lapangan Usaha 
pemerintahan, pertanahan dan jaminan sosial wajib, (8) sektor jasa kesehatan dan kegiatan sosial, dan (9) sektor jasa lainnya. Hal ini dikarenakan kesembilan sektor tersebut mengalami pertumbuhan yang lebih lambat dibandingkan dengan pertumbuhan sektor yang sama di tingkat Provinsi Sulawesi Utara. Berdasarkan kriteria untuk menentukan suatu sektor unggulan adalah sektor yang maju dan tumbuh pesat, basis, dan kompetitif maka sektor ekonomi yang masuk dalam katagori tersebut adalah: (1) Sektor Pertanian, Kehutanan dan Perikanan, dan (2) Sektor Pertambangan dan Penggalian.

\section{Hasil Analisis SWOT}

Analisis potensi pengembangan secara internal adalah analisis terhadap Kekuatan (Strength) dan secara eksternal adalah analisis terhadap Peluang (Opportunity) yang dimiliki Kabupaten Bolaang Mongondow Timur. Sedangkan analisis permasalahan pengembangan secara internal adalah analisis terhadap Kelemahan (weakness) dan secara eksternal adalah analisis terhadap Tantangan (threat) yang harus dihadapi oleh Kabupaten Bolaang Mongondow Timur dalam pengembangan wilayah Kabupaten Bolaang Mongondow Timur dengan memperhatikan hasil analisis sektor unggulan. Berdasarkan dokumen-dokumen dan wawancara dengan

Tabel 8 Analisis Shift-share Klasik

untuk Kabupaten Bolaang Mongondow Timur, 2010 dan 2016

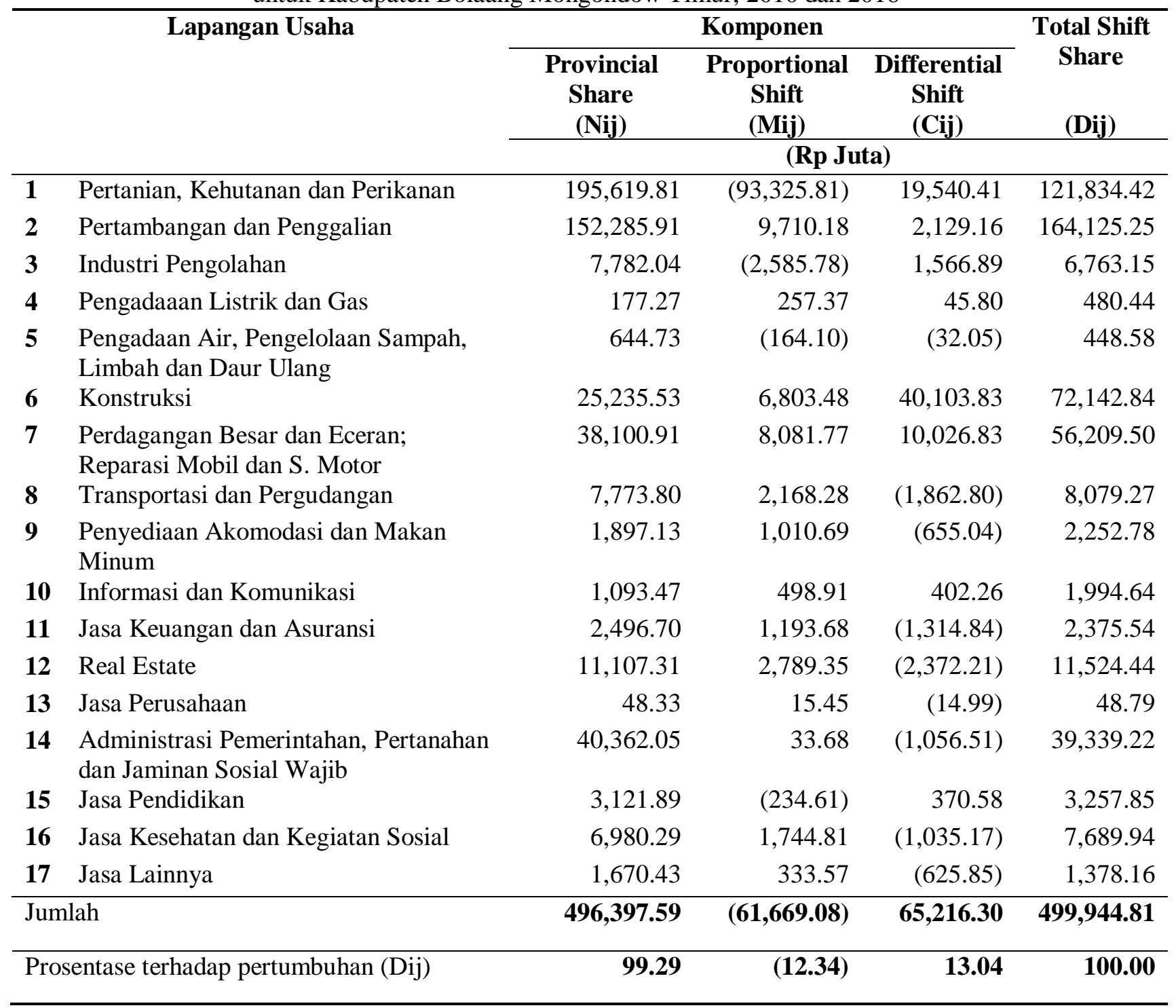

Sumber: Hasil Analisis, 2017 
Tabel 9 Tipologi Klassen, Location Quotient, dan Shift-Share Sektor Ekonomi Kabupaten Bolaang Mongondow Timur

\begin{tabular}{|c|c|c|c|c|}
\hline & Lapangan Usaha & Tipologi Klassen & $\begin{array}{l}\text { Location } \\
\text { Quotient }\end{array}$ & $\begin{array}{l}\text { Differential } \\
\text { Shift }\end{array}$ \\
\hline 1 & Pertanian, Kehutanan dan Perikanan & Maju dan Tumbuh Pesat & Basis & Kompetitif \\
\hline 2 & Pertambangan dan Penggalian & Maju dan Tumbuh Pesat & Basis & Kompetitif \\
\hline 3 & Industri Pengolahan & Potensial & Non Basis & Kompetitif \\
\hline 4 & Pengadaaan Listrik dan Gas & Potensial & Non Basis & Kompetitif \\
\hline 5 & $\begin{array}{l}\text { Pengadaan Air, Pengelolaan Sampah, } \\
\text { Limbah dan Daur Ulang }\end{array}$ & Relatif Tertinggal & Non Basis & $\begin{array}{c}\text { Tidak } \\
\text { Kompetitif }\end{array}$ \\
\hline 6 & Konstruksi & Potensial & Non Basis & Kompetitif \\
\hline 7 & $\begin{array}{l}\text { Perdagangan Besar dan Eceran; } \\
\text { Reparasi Mobil dan S. Motor }\end{array}$ & Potensial & Non Basis & Kompetitif \\
\hline 8 & Transportasi dan Pergudangan & Relatif Tertinggal & Non Basis & $\begin{array}{c}\text { Tidak } \\
\text { Kompetitif }\end{array}$ \\
\hline 9 & $\begin{array}{l}\text { Penyediaan Akomodasi dan Makan } \\
\text { Minum }\end{array}$ & Relatif Tertinggal & Non Basis & $\begin{array}{l}\text { Tidak } \\
\text { Kompetitif }\end{array}$ \\
\hline 10 & Informasi dan Komunikasi & Potensial & Non Basis & Kompetitif \\
\hline 11 & Jasa Keuangan dan Asuransi & Relatif Tertinggal & Non Basis & $\begin{array}{c}\text { Tidak } \\
\text { Kompetitif }\end{array}$ \\
\hline 12 & Real Estate & Relatif Tertinggal & Non Basis & $\begin{array}{c}\text { Tidak } \\
\text { Kompetitif }\end{array}$ \\
\hline 13 & Jasa Perusahaan & Relatif Tertinggal & Non Basis & $\begin{array}{c}\text { Tidak } \\
\text { Kompetitif }\end{array}$ \\
\hline 14 & $\begin{array}{l}\text { Administrasi Pemerintahan, Pertanahan } \\
\text { dan Jaminan Sosial Wajib }\end{array}$ & Maju tapi Tertekan & Basis & $\begin{array}{c}\text { Tidak } \\
\text { Kompetitif }\end{array}$ \\
\hline 15 & Jasa Pendidikan & Potensial & Non Basis & Kompetitif \\
\hline 16 & Jasa Kesehatan dan Kegiatan Sosial & Relatif Tertinggal & Non Basis & $\begin{array}{c}\text { Tidak } \\
\text { Kompetitif }\end{array}$ \\
\hline 17 & Jasa Lainnya & Relatif Tertinggal & Non Basis & $\begin{array}{l}\text { Tidak } \\
\text { Kompetitif }\end{array}$ \\
\hline
\end{tabular}

Sumber: Hasil Analisis, 2017

Tabel 10 Pembobotan Faktor-Faktor Strategis

\begin{tabular}{clc}
\hline No & \multicolumn{1}{c}{ Faktor Strategis (Internal) } & Bobot \\
\hline A & Potensi sumber daya alam & 0.11 \\
B & Tenaga kerja di sektor pertanian cukup besar & 0.09 \\
C & Potensi ekonomi sektor unggulan & 0.10 \\
D & Dukungan kebijakan pemerintah daerah & 0.11 \\
E & Degradasi lingkungan akibat aktivitas pertambangan & 0.12 \\
F & Pola pikir petani/nelayan & 0.07 \\
G & Kualitas tenaga kerja & 0.11 \\
H & Perkebunan rakyat masih menggunakan cara-cara & 0.07 \\
& tradisional & \\
I & Ketersediaan infrastruktur & 0.11 \\
J & Kapasitas dan kinerja kelembagaan & 0.10 \\
\hline
\end{tabular}

Sumber: Penilaian responden atas kuisioner SWOT, 2017 
pemerintah daerah serta gambaran umum wilayah Kabupaten Bolaang Mongondow Timur, maka diperoleh elemen faktor-faktor internal dan eksternal. Hasil identifikasi faktorfaktor strategis tersebut adalah sebagai berikut:

\section{Faktor-faktor Strategis Internal}

Analisis kondisi internal dilakukan terhadap faktor-faktor strategis yang terdiri atas kekuatan dan kelemahan dalam pengembangan wilayah Kabupaten Bolaang Mongondow Timur dengan memperhatikan hasil analisis sektor unggulan. Adapun faktor-faktor strategis internal tersebut adalah:

\section{a. Kekuatan}

1) Potensi sumber daya alam untuk pengembangan sektor Pertambangan dan Energi, Agropolitan, Kehutanan dan Perikanan

2) Jumlah pekerja di sektor pertanian cukup besar yaitu $51,77 \%$ (16.266 jiwa) dari total jumlah penduduk yang bekerja (31.415 jiwa) berdasarkan data tahun 2015 .

3) Potensi ekonomi sektor unggulan yaitu sektor pertanian, kehutanan dan perikanan yang merupakan kontributor terbesar bagi PDRB Kabupaten Bolaang Mongondow Timur sebesar $34,75 \%$ pada tahun 2016 (sumber: BPS Kab. Bolaang Mongondow Timur tahun 2017). Sektor pertanian meliputi beberapa subsektor, yaitu subsektor pertanian, peternakan dan jasa pertanian yang memberikan kontribusi terbesar diikuti oleh subsektor perikanan dan yang terendah kontribusinya adalah subsektor kehutanan dan penebangan kayu. Sektor unggulan lainnya yaitu sektor pertambangan merupakan kontributor kedua bagi PDRB Kabupaten Bolaang Mongondow Timur sebesar 31,34\% pada tahun 2016.

4) Adanya kebijakan pemerintah daerah bahwa pembangunan Bolaang Mongondow Timur yang bertumpu pada sektor Pertanian dan Perkebunan, Kelautan dan Perikanan, Perdagangan dan Jasa, sektor Pariwisata serta pertambangan.

\section{b. Kelemahan}

1) Adanya degradasi lingkungan akibat aktivitas pertambangan. Kondisi air permukaan mengalami penurunan kualitas karena limbah penambangan emas. Hal ini menyebabkan Kabupaten Bolaang Mongondow Timur masuk dalam kategori awas tambang.
2) Pola pikir petani/nelayan yang cenderung belum berwawasan agribisnis

3) Kualitas tenaga kerja yang tersedia mencakup pengetahuan, keterampilan, disiplin, dan etos kerja kebanyakan belum memenuhi kebutuhan pasar serta kepentingan pembangunan daerah

4) Perkebunan yang terdapat di Kabupaten Bolaang Mongondow Timur sebagian besar merupakan perkebunan rakyat. Pekebun masih mengusahakan lahannya dengan cara-cara tradisional, maka hasil pasca panen juga berkualitas rendah sehingga harga jual relatif rendah. Hasil perkebunan dijual dalam bentuk segar ataupun diolah tetapi secara sederhana sehingga tidak memberikan banyak keuntungan bagi pekebun karena produknya tidak memiliki nilai tambah.

5) Ketersediaan infrastruktur ekonomi seperti jalan, listrik dan telekomunikasi belum memadai. Tingginya tingkat kerusakan jalan kabupaten, terlihat dari data jalan kondisi rusak berat mencapai $62 \%$ atau $370,52 \mathrm{~km}$ dari total panjang jalan kabupaten yaitu $551,03 \mathrm{~km}$. Ketersediaan energi listrik masih sangat memprihatinkan, karena seringnya terjadi pemadaman listrik. Hal ini tentunya sangat rentan terhadap investasi dan kegiatan ekonomi masyarakat. Demikian juga dengan ketersediaan sarana/prasarana pertanian yang masih tersedia terbatas seperti jaringan irigasi, jalan usaha tani, laboratorium dan kebun percobaan bagi penelitian, laboratorium penangkaran benih, dan lain-lain.

6) Kapasitas dan kinerja kelembagaan belum optimal. Kinerja lembaga-lembaga yang ada di Kabupaten Bolaang Mongondow Timur belum cukup baik untuk menunjang pembangunan daerah.

Setelah melakukan identifikasi faktor-faktor strategis internal, maka dilakukan pembobotan. Hasil pembobotan masing-masing faktor strategis internal berdasarkan penilaian responden, seperti tercantum dalam lampiran 1 yang secara ringkas dapat dijelaskan pada Tabel 1 Hasil pembobotan faktor-faktor strategis internal menunjukkan bahwa degradasi lingkungan akibat aktivitas pertambangan merupakan faktor strategis internal yang terpenting $(0,12)$. Faktor-faktor strategis internal yang juga dipandang penting adalah potensi sumber daya alam, dukungan kebijakan pemerintah, kualitas tenaga kerja dan ketersediaan infrastruktur.

Tahap selanjutnya setelah memperoleh bobot masing-masing faktor strategis internal adalah melakukan penilaian (rating) terhadap faktor- 
Tabel 11 Matriks Internal Factor Evaluation (IFE)

\begin{tabular}{llrrr}
\hline \multicolumn{1}{c}{ Faktor Strategis Internal } & Bobot & Rating & Skor \\
\hline A & Kekuatan & 0.11 & 2.67 & 0.31 \\
$\mathbf{1}$ & Potensi sumber daya alam & 0.09 & 3.00 & 0.27 \\
$\mathbf{2}$ & Tenaga kerja di sektor pertanian cukup besar & 0.10 & 3.67 & 0.38 \\
$\mathbf{3}$ & Potensi ekonomi sektor unggulan & 0.11 & 3.33 & 0.35 \\
$\mathbf{4}$ & Dukungan kebijakan pemerintah daerah & 0.42 & 12.67 & 1.31 \\
& Sub Total & & & \\
B & Kelemahan & 0.12 & 4.00 & 0.46 \\
$\mathbf{5}$ & Degradasi lingkungan & 0.07 & 2.67 & 0.20 \\
$\mathbf{6}$ & Pola pikir petani/nelayan & 0.11 & 3.67 & 0.42 \\
$\mathbf{7}$ & Kualitas tenaga kerja & 0.07 & 2.67 & 0.18 \\
$\mathbf{8}$ & Perkebunan rakyat dengan cara tradisional & 0.11 & 4.00 & 0.44 \\
$\mathbf{9}$ & Ketersediaan infrastruktur & 0.10 & 3.000 & 0.31 \\
$\mathbf{1 0}$ & Kapasitas dan kinerja kelembagaan & 0.58 & 20.00 & 2.01 \\
& Sub Total & 1,00 & & 3.32 \\
\hline
\end{tabular}

Sumber: Hasil Analisis, 2017

faktor kunci internal ke dalam matriks IFE (Internal Factor Evaluation). Penilaian (rating) dilakukan oleh responden seperti tercantum dalam lampiran 2 yang secara ringkas dapat dijelaskan pada Tabel 11 Berdasarkan hasil penilaian pada Tabel 11, dapat diketahui bahwa kekuatan utama dalam pengembangan wilayah di kabupaten Bolaang Mongondow Timur yang berbasis sektor unggulan ialah potensi ekonomi sektor unggulan, dukungan kebijakan pemerintah daerah dan potensi sumber daya alam. Sebaliknya, kelemahan utama adalah degradasi lingkungan, ketersediaan infrastruktur dan kualitas tenaga kerja.

Total nilai untuk faktor kekuatan adalah 1,31 sedangkan total nilai faktor kelemahan adalah 2,01. Hal ini menunjukkan bahwa faktor kelemahan lebih besar dibandingkan dengan faktor kekuatan.

2. Faktor-faktor Strategis Eksternal

Analisis kondisi eksternal dilakukan terhadap faktor-faktor strategis yang terdiri atas peluang dan ancaman dalam pengembangan wilayah Kabupaten Bolaang Mongondow Timur dengan memperhatikan hasil analisis sektor unggulan. Adapun faktor-faktor strategis eksternal tersebut adalah :

a. Peluang

1. Melalui kebijakan UU no 32 tahun 2002 tentang Pemerintahan Daerah serta UU no 28 tahun 2008 tentang pembentukan Kabupaten Bolaang Mongondow Timur, maka pemerintah Kabupaten Bolaang Mongondow Timur dapat melaksanakan otonomi daerah dimana pemerintah daerah dapat mengembangkan daerahnya berdasarkan kondisi lokal dan selain itu juga dapat mengelolan sumber daya yang ada secara mandiri.

2) Kedudukan dan posisi wilayah Kabupaten Bolaang Mongondow Timur secara regional yang terletak di tengah-tengan wilayah Provinsi Sulawesi Utara merupakan posisi yang menguntungkan dan strategis bagi pengembangan wilayah. Kedudukan ini dapat menciptakan peranan dan fungsi wilayah kabupaten baik di lingkup eksternal maupun internal wilayah. Mudah diakses karena terletak di antara wilayah lainnya yang sedang dikembangkan memberi peluang kemudahan aliran barang dan jasa sehingga dapat menunjang perekonomian.

4) Kemajuan teknologi yang sangat pesat merupakan faktor penting dalam pembangunan. Dengan adanya kemajuan teknologi yang ada sekarang ini, sektorsektor ekonomi yang ada di Kabupaten Bolaang Mongondow Timur diharapkan dapat menyesuaikan diri secara bertahap sehingga mampu menghasilkan produkproduk unggulan yang mampu bersaing dengan produk daerah atau negara lain.

5) Dukungan pemerintah pusat dalam bentuk transfer ke daerah. Sampai saat ini, Kabupaten Bolaang Mongondow Timur masih sangat tergantung pada transfer pemerintah pusat karena belum dapat 
Tabel 12 Faktor-Faktor Strategis Eksternal

\begin{tabular}{clc}
\hline No & \multicolumn{1}{c}{ Faktor Strategis (Eksternal) } & Bobot \\
\hline A & Undang-undang otonomi daerah & 0.10 \\
B & Posisi strategis bagi pengembangan wilayah . & 0.09 \\
C & Hubungan ekonomi telah terbentuk dengan daerah sekitar & 0.09 \\
$\mathbf{D}$ & Kemajuan teknologi yang sangat pesat & 0.08 \\
$\mathbf{E}$ & Dukungan pendanaan pemerintah pusat & 0.11 \\
$\mathbf{F}$ & Keterlibatan swasta & 0.10 \\
$\mathbf{G}$ & Tantangan kompetisi wilayah sekitar yang sudah maju & 0.09 \\
$\mathbf{H}$ & Harga jual yang tidak pasti dan serangan penyakit pada tanaman & 0.14 \\
$\mathbf{I}$ & Tenaga kerja dari luar yang lebih terdidik dan terlatih & 0.09 \\
$\mathbf{J}$ & Globalisasi, pasar bebas dan keterbukaan ekonomi dunia & 0.09 \\
\hline
\end{tabular}

Sumber: Penilaian responden atas kuisioner SWOT, 2017

mengoptimalkan kewenangan otonomi daerah, maka dukungan pemerintah pusat dalam bentuk transfer ini merupakan peluang besar dalam rangka melaksanakan pembangunan, sehingga harus dimanfaatkan sesuai dengan prioritas yang telah disusun.

6) Adanya keterlibatan swasta dalam pengembangan sektor pertanian khususnya sub sektor perkebunan. Kabupaten Bolaang Mongondow Timur memiliki 2 (dua) perkebunan besar swasta yang seluruhnya mengembangkan komoditas kelapa. Produksi yang dihasilkan berupa kopra dan pemasarannya dilakukan langsung oleh perusahaan. Lokasi Perkebunan Besar Swasta (PBS) kelapa adalah di Kecamatan Tutuyan. Perkebunan besar ini menggunakan tenaga kerja lokal sebagai tenaga penanam sedangkan untuk pengolahan, perusahaan lebih banyak menggunakan tenaga kerja profesional dari luar.

b. Ancaman

7) Adanya tantangan kompetisi wilayah sekitarnya seperti Ratahan, Kotamobagu yang relatif lebih maju.

8) Harga jual yang tidak pasti dan serangan penyakit pada tanaman menurunkan produksi dan merugikan petani.

9) Tenaga kerja dari luar yang lebih terdidik dan terlatih sehingga penduduk lokal sulit bersaing.

10) Globalisasi, pasar bebas dan keterbukaan ekonomi dunia. Pada masa globalisasi, peran daerah menjadi sangat penting, dan menjadi pemeran utama dalam kegiatan perekonomian. Oleh karena itu dibutuhkan kesiapan daerah untuk ikut berperan serta dalam perekonomian global. Apabila Kabupaten Bolaang Mongondow Timur tidak dengan segera meningkatkan daya saingnya, maka Kabupaten Bolaang Mongondow Timur tidak akan bisa bersaing di masa keterbukaan ekonomi seperti sekarang ini.

Setelah melakukan identifikasi faktor-faktor strategis eksternal, maka dilakukan pembobotan. Hasil pembobotan masing faktor strategis internal berdasarkan penilaian responden, seperti tercantum dalam lampiran 3 yang secara ringkas dapat dijelaskan pada Tabel 12 Hasil pembobotan faktor-faktor strategis eksternal pada Tabel 12 menunjukkan bahwa harga jual yang tidak pasti dan serangan penyakit pada tanaman merupakan faktor strategis eksternal yang terpenting $(0,14)$. Faktor-faktor strategis eksternal yang juga dipandang penting adalah dukungan pendanaan pemerintah pusat dan undang-undang otonomi daerah.

Tahap selanjutnya setelah memperoleh bobot masing-masing faktor strategis eksternal adalah melakukan penilaian (rating) terhadap faktorfaktor kunci internal ke dalam matriks EFE (External Factor Evaluation). Penilaian (rating) dilakukan oleh responden seperti tercantum dalam lampiran 4 yang secara ringkas dijelaskan pada Tabel 13. Berdasarkan hasil penilaian pada Tabel 13, maka dapat diketahui bahwa peluang utama dalam pengambangan wilayah kabupaten Bolaang Mongondow Timur yang berbasis sektor unggulan adalah dukungan pemerintah pusat dan yang menjadi ancaman utama adalah harga jual dan serangan penyakit pada tanaman. Total nilai padafaktor peluang adalah 1,95 sedangkan total nilai Kabupaten Bolaang Mongondow Timur dengan 


\begin{tabular}{|c|c|c|c|c|}
\hline \multicolumn{5}{|c|}{ Tabel 13 Matriks External Factor Evaluation (EFE) } \\
\hline & Faktor Strategis Eksternal & Bobot & Rating & Skor \\
\hline $\mathbf{A}$ & Peluang & & & \\
\hline 1 & Undang-undang tentang otonomi daerah & 0.10 & 3.67 & 0.36 \\
\hline 2 & Posisi strategis bagi pengembangan wilayah . & 0.09 & 2.67 & 0.23 \\
\hline 3 & Hubungan ekonomi telah terbentuk dengan daerah sekitar & 0.10 & 3.67 & 0.35 \\
\hline 4 & Kemajuan teknologi yang sangat pesat & 0.09 & 3.00 & 0.26 \\
\hline 5 & Dukungan pendanaan pemerintah pusat & 0.11 & 4.00 & 0.46 \\
\hline \multirow[t]{2}{*}{6} & Adanya keterlibatan swasta & 0.10 & 3.00 & 0.30 \\
\hline & Sub Total & 0.58 & 20.00 & 1.95 \\
\hline B & Ancaman & & & \\
\hline 7 & Tantangan kompetisi wilayah sekitar yang lebih maju & 0.09 & 2.67 & 0.24 \\
\hline 8 & Harga jual dan serangan penyakit pada tanaman & 0.14 & 2.67 & 0.37 \\
\hline 9 & Tenaga kerja dari luar yang lebih terdidik dan terlatih & 0.10 & 3.00 & 0.29 \\
\hline \multirow[t]{3}{*}{10} & Globalisasi dan keterbukaan ekonomi dunia & 0.10 & 2.67 & 0.25 \\
\hline & Sub Total & 0.42 & 11.00 & 1.15 \\
\hline & Total & 1.00 & & 3.10 \\
\hline
\end{tabular}

Sumber: Hasil Analisis, 2017

berbasis sektor unggulan memiliki faktor peluang yang lebih besar dari faktor ancaman. Diagram SWOT

Hasil yang diperoleh dari matriks IFE dan matriks EFE dipetakan ke dalam diagram SWOT (Gambar 5).

Perhitungan analisis SWOT adalah sebagai berikut:

a. Selisih dari faktor peluang dan ancaman untuk mendapatkan titik Y

$$
\begin{array}{ll}
\text { Peluang } & =1,95 \\
\text { Ancaman } & =1,15 \\
\text { Titik Y } & =1,95-1,15=0,8
\end{array}
$$

b. Selisih dari faktor kekuatan dan kelemahan untuk mendapatkan titik X.

$$
\begin{array}{ll}
\text { Kekuatan } & =1,31 \\
\text { Kelemahan } & =2,01 \\
\text { Titik X } & =1,31-2,01=-0,7
\end{array}
$$

Berdasarkan pada perhitungan diatas dapat ditentukan posisi pengembangan wilayah Kabupaten Bolaang Mongondow Timur dengan berbasis sektor unggulan berada pada titik koordinat $(-0,7 ; 0,8)$ yang berarti berada pada kuadran III sehingga strategi yang sesuai adalah strategi perubahan haluan atau strategi berbalik (turnaround). Matriks SWOT

Penyusunan matriks SWOT untuk mengintegrasikan faktor strategis internal dan eksternal. matriks diatas menggambarkan secara jelas bagaimana peluang dan ancaman (eksternal) yang dihadapi dapat disesuaikan dengan kekuatan dan kelemahan yang dimiliki. (Lihat Tabel 14). Strategi W O pada kuadran III, berarti meminimalkan kelemahan dengan memanfaatkan peluang. Adapun Strategi W O adalah sebagai berikut :
1. Meminimalkan degradasi lingkungan akibat aktivitas pertambangan melalui pemanfaatan teknologi yang ramah lingkungan

2. Mentransformasikan pola pikir agribisnis kepada petani/nelayan dengan melibatkan swasta/dunia usaha

3. Meningkatkan kualitas tenaga kerja yang mencakup pengetahuan, ketrampilan, dan etos kerja agar memenuhi kebutuhan pasar melalui pendidikan/pelatihan dengan memanfaatkan dukungan pemerintah pusat mupun swasta/dunia usaha

4. Meningkatkan produksi maupun kualitas hasil pasca panen melalui pemanfaatan kemajuan ilmu pengetahuan dan teknologi

5. Meningkatkan penyediaan infrastruktur/sarana dan prasarana melalui dukungan pendanaan pemerintah pusat.

6. Meningkatkan kapasitas dan kinerja kelembagaan untuk dapat memanfaatkan kewenangan otonomi daerah sebagai amanat undang-undang agar pemerintah daerah dapat mengelola sumber daya yang ada secara mandiri.

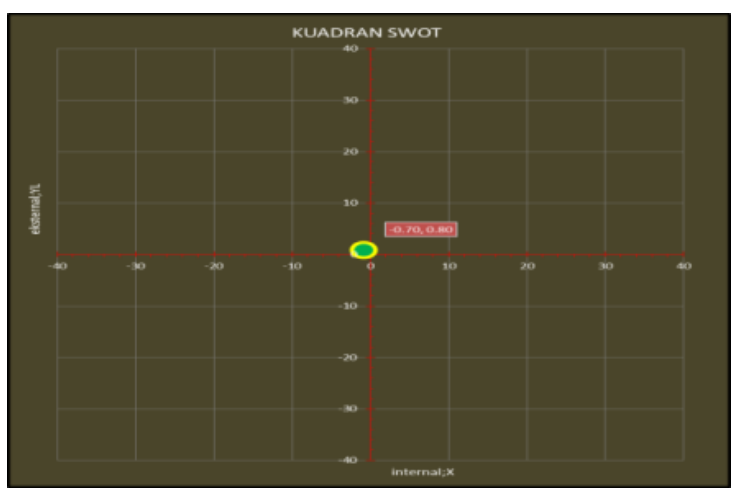




\section{Tabel 14 Matriks SWOT}

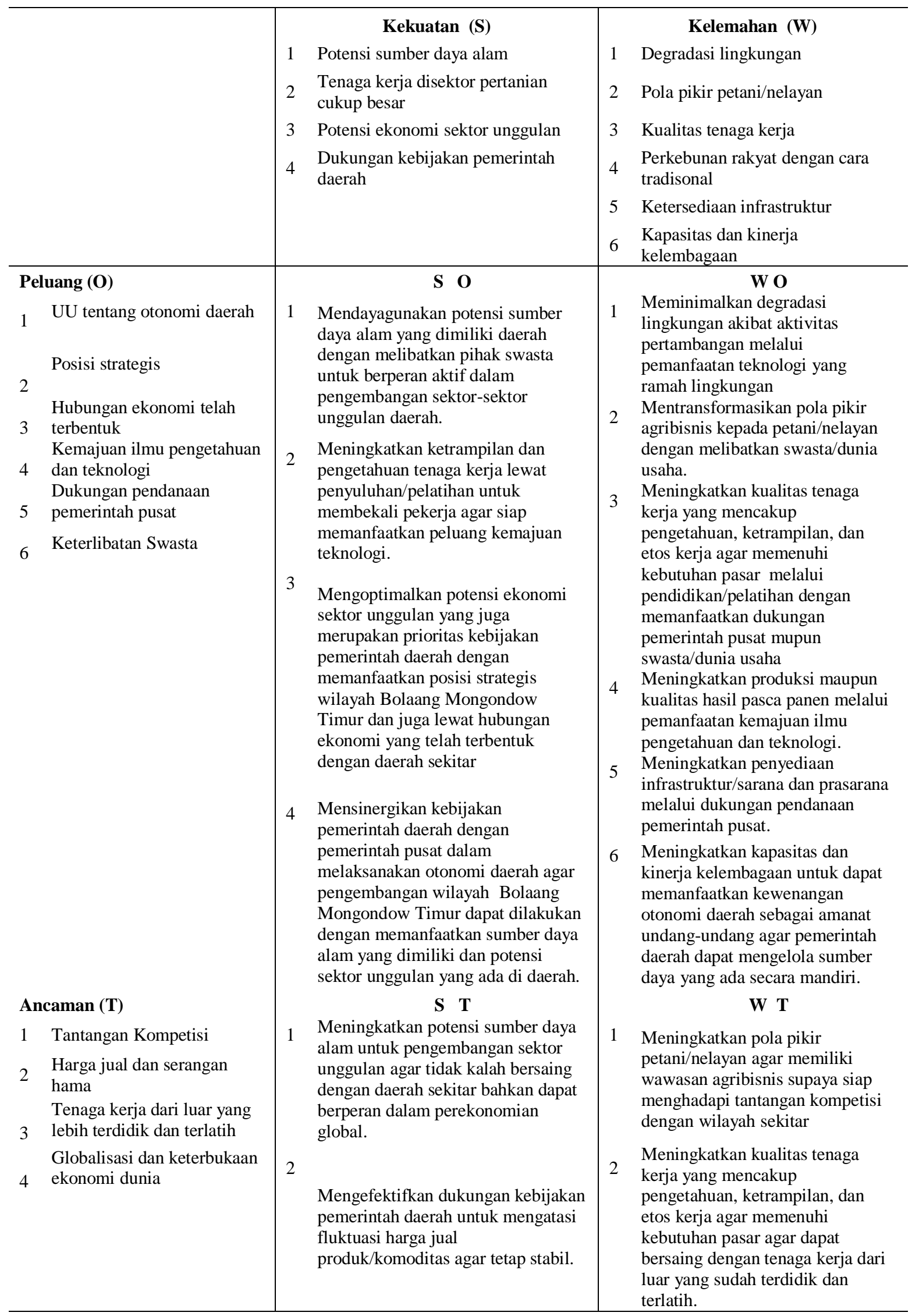

Sumber: Hasil Analisis, 2017 


\section{KESIMPULAN DAN SARAN}

\section{Kesimpulan}

Hasil penelitian ini dapat ditarik beberapa kesimpulan sebagai berikut :

1. Sektor ekonomi Kabupaten Bolaang Mongondow Timur yang tergolong sektor unggulan berdasarkan kriteria sektor maju dan tumbuh pesat, basis, dan kompetitif maka sektor ekonomi yang masuk dalam katagori tersebut adalah: (1) Sektor Pertanian, Kehutanan dan Perikanan, dan (2) Sektor Pertambangan dan Penggalian.

2. Berdasarkan analisis SWOT posisi pengembangan wilayah Kabupaten Bolaang Mongondow Timur dengan berbasis sektor unggulan berada pada kuadran III sehingga strategi yang sesuai adalah strategi perubahan haluan atau strategi berbalik (turnaround). Strategi W O pada kuadran III, berarti meminimalkan kelemahan dengan memanfaatkan peluang. Adapun Strategi W $\mathrm{O}$ adalah sebagai berikut:

a. Meminimalkan degradasi lingkungan akibat aktivitas pertambangan melalui pemanfaatan teknologi yang ramah lingkungan.

b. Mentransformasikan pola pikir agribisnis kepada petani/nelayan dengan melibatkan swasta/dunia usaha

c. Meningkatkan kualitas tenaga kerja yang mencakup pengetahuan, ketrampilan, dan etos kerja agar memenuhi kebutuhan pasar melalui pendidikan/pelatihan dengan memanfaatkan dukungan pemerintah pusat maupun swasta/dunia usaha

d. Meningkatkan produksi maupun kualitas hasil pasca panen melalui pemanfaatan kemajuan ilmu pengetahuan dan teknologi

e. Meningkatkan penyediaan infrastruktur/sarana dan prasarana melalui dukungan pendanaan pemerintah pusat.

f. Meningkatkan kapasitas dan kinerja kelembagaan untuk dapat memanfaatkan kewenangan otonomi daerah sebagai amanat undang-undang agar pemerintah daerah dapat mengelola sumber daya yang ada secara mandiri.

\section{Saran}

Berdasarkan hasil simpulan di atas maka beberapa saran yang dapat diberikan adalah:
1. Memprioritaskan pengembangan pembangunan ekonomi pada sektor sektor Pertanian, Kehutanan dan Perikanan, Pertambangan dan Penggalian sebagai sektor unggulan serta sektor basis lainnya sebagai sektor penggerak utama kegiatan perekonomian Kabupaten Bolaang Mongondow Timur yaitu sektor Administrasi Pemerintah, Pertanahan dan Jaminan Sosial Wajib.

2. Meskipun sektor industri pengolahan, sektor pengadaan listrik dan gas, sektor konstruksi, sektor perdagangan besar dan eceran; reparasi mobil dan sepeda motor, sektor informasi dan komunikasi, dan sektor jasa pendidikan bukan sektor basis namun keduanya memiliki tingkat kompetisi yang baik dan berpotensi untuk berkembang sehingga perlu mendapat perhatian serius untuk dikelola dan dikembangkan menjadi sektor basis di masa mendatang.

3. Keseriusan pemerintah dan masyarakat menjaga lingkungan hidup dari berbagai bentuk pencemaran serta kemampuan pemerintah dan masyarakat mendorong partisipasi aktf sektor swasta dalam menjamin terjaganya kualitas ekosistim dan lingkungan hidup dengan prinsip pembangunan berkelanjutan.

\section{DAFTAR PUSTAKA}

Asmarani, A.S. 2010. Strategi Kebijakan Pembangunan Daerah Kabupaten Klaten; Pendekatan Analisa SWOT dan AHP. Tesis Program Magister Perencana dan Kebijakan Publik. Universitas Indonesia. Jakarta. Hal 67-76

Badan Pengkajian dan Penerapan Teknologi Deputi Pengkajian Kebijakan Teknologi. Pengembangan Wilayah dan Otonomi Daerah.2002

BPS Kabupaten Bolaang Mongondow Timur, 2017. Kabupaten Bolaang Mongondow Timur Dalam Angka 2017. Bolaang Mongondow Timur : BPS Kabupaten Bolaang Mongondow Timur

Brojonegoro, P.S. Bambang. 1992. AHP (the Analytical Hierarchy Process). Pusat Antar University - Studi Ekonomi Universitas Indonesia 
Fachrurrazy, 2009. Analisis Penentuan Sektor Unggulan Perekonomian Wilayah Kabupaten Acah Utara Dengan Pendekatan Sektor Pembentuk PDRB. Tesis Program Pascasarjana Universitas Sumatera Utara, Medan

Haryanto, Joko Tri. 2004. Potret PAD dan Relevansinya Terhadap Kemandirian Daerah. Departemen Keuangan Indonesia.

Kabupaten Bolaang Mongondow Timur Dalam Angka. 2017

Mankiw, Gregory. 2006. Makroekonomi. Penerbit Erlangga. Jakarta

Nadiyatul Huda Mangun. 2007. Analisis Potensi Ekonomi Regional Kabupaten Kota di Provinsi Sulawesi Tengah. Universitas Halueleo

Rizal Endi, I Wayan Suparta, Muhammad Husain Analisis Sektor Unggulan Dan Pengembangan Wilayah Di Kota Bandar Lampung 20002012

Rustiadi E., Saefulhakim, dan Panuju D.R. 2011. Perencanaan dan Pengembangan Wilayah. Yayasan Pustaka Obor Indonesia, Jakarta

Soesilo, I Nining. 2002. Reformasi Pembangunan Perlu Pendekatan Manajemen Strategik, Buku I. Universitas Indonesia.
Sjafrizal. 1997. Pertumbuhan Ekonomi dan Ketimpangan Regionl Wilayah Indonesia Bagian Barat. Prisma. LP3ES No. 3 Tahun XXVI. Jakarta

Sugeng Budiharsono.2001. Teknik Analisis Pembangunan Wilayah Pesisir dan Lautan. Pradnya Paramita, Jakarta.

Sukirno, Sadono. 1976. Beberapa Aspek Dalam Persoalan Pembangunan Daerah. Lembaga Penerbit Fakultas Ekonomi. Universitas Indonesia. Jakarta.

Susantono, Bambang. 2009. Strategi dalam Penataan Ruang dan Pengembangan Wilayah. Kata Hasta Pustaka, Jakarta.

Suyatno, 2000. Analisa Econimic Base terhadap Pertumbuhan Ekonomi Daerah Tingkat II Wonogiri : Menghadapi Implementasi UU No. 22/1999 dan UU No. 25/1999. Dalam Jurnal Ekonomi Pembangunan Vol. 1. No. 2. Hal. 144-159. Surakarta: UMS

Sjafrizal. 1997. Pertumbuhan Ekonomi dan Ketimpangan Regionl Wilayah Indonesia Bagian Barat. Prisma. LP3ES No. 3 Tahun XXVI. Jakarta

Tarigan, R. 2005. Perencanaan Pembangunan Wilayah. Bumi Aksara, Jakarta.

Tarigan, R. 2005. Ekonomi Regional. Bumi Aksara, Jakarta. 